\title{
A study of ribonuclease activity in venom of vietnam cobra
}

\author{
Thiet Van Nguyen ${ }^{1 *}$ and A. V. Osipov ${ }^{2}$
}

\begin{abstract}
Background: Ribonuclease (RNase) is one of the few toxic proteins that are present constantly in snake venoms of all types. However, to date this RNase is still poorly studied in comparison not only with other toxic proteins of snake venom, but also with the enzymes of RNase group. The objective of this paper was to investigate some properties of RNase from venom of Vietnam cobra Naja atra.
\end{abstract}

Methods: Kinetic methods and gel filtration chromatography were used to investigate RNase from venom of Vietnam cobra.

Results: RNase from venom of Vietnam cobra Naja atra has some characteristic properties. This RNase is a thermostable enzyme and has high conformational stability. This is the only acidic enzyme of the RNase A superfamily exhibiting a high catalytic activity in the $\mathrm{pH}$ range of $1-4$, with $\mathrm{pH}_{\mathrm{opt}}=2.58 \pm 0.35$. Its activity is considerably reduced with increasing ionic strength of reaction mixture. Venom proteins are separated by gel filtration into four peaks with ribonucleolytic activity, which is abnormally distributed among the isoforms: only a small part of the RNase activity is present in fractions of proteins with molecular weights of 12-15 kDa and more than $30 \mathrm{kDa}$, but most of the enzyme activity is detected in fractions of polypeptides, having molecular weights of less than $9 \mathrm{kDa}$, that is unexpected.

Conclusions: RNase from the venom of Vietnam cobra is a unique member of RNase A superfamily according to its acidic optimum pH ( $\mathrm{pH}_{\mathrm{opt}}=2.58 \pm 0.35$ ) and extremely low molecular weights of its major isoforms (approximately $8.95 \mathrm{kDa}$ for RNase III and $5.93 \mathrm{kDa}$ for RNase IV).

Keywords: Acidic optimum pH, Conformational stability, Gel filtration, lonic strength, Isoforms, Thermostability, Venom RNase, Vietnam cobra

\section{Background}

Since ancient times snake venom has been considered as the precious medicinal source. Not by chance that the symbol of medicine in all over the world is the image of a snake releasing venom. Today we know that snake venom is the source, very rich in biologically active substances, such as toxins, proteins, enzymes and toxic peptides. Snake venom affects many organs and organ systems in the body such as the nervous system, blood and cardiovascular system, respiratory and muscular systems... Snake venom is used to treat various diseases, including cardiovascular diseases [1], hypertension [2] and osteoarthritis [3]. The venom of some snakes showed

\footnotetext{
* Correspondence: nvthiet@ibt.ac.vn

${ }^{1}$ Institute of Biotechnology, Vietnam Academy of Science and Technology (VAST), Hanoi, Vietnam

Full list of author information is available at the end of the article
}

anti-cancer effects and is used to develop anti-cancer drugs [4-7].

Snake venom is a biological fluid having the highest RNase activity [8]. RNase is one of the toxic enzymes that are permanently present in snake venoms of all kinds $[9,10]$. However, up to now snake venom RNase is little studied in comparison not only with the enzymes of RNase group, but also with the other proteins of snake venoms. Probably this is the reason that so far we still do not understand the role of this enzyme in the toxic action of the snake venoms in general.

Moreover, snake venom RNase is a secreted enzyme, so this RNase belongs to the RNase A superfamily. At present has been known that the RNase A superfamily is a large family of secreted RNases in vertebrates from amphibians to mammals, including species Homo sapiens with RNase A (an enzyme from 
bovine pancreas) as a prototype $[11,12]$. In the last time the main function of the enzymes of RNase A superfamily is thought to be involved in the host defense system. Many members of this superfamily possess antimicrobial [13-19], antiviral [20-23], cytotoxic [24-29] and other biological actions [26, 30-32], as observed for the most of RNases of the RNase A superfamily in human [33-35] and for RNases of this superfamily in other organisms [13, 19, 26, 36, 37]. From this context, we believe that the permanent presence of RNase in snake venoms of all kinds is not accidental; and the fact that snake venom is a biological fluid having very high ribonucleolytic activity may reflect a certain role of this enzyme in the toxic effects of snake venom.

In this work, the results of studying some properties of RNase from the venom of Vietnam cobra will be presented. Information about these properties may help to understand the role of RNase in general toxic effects of snake venom.

\section{Methods}

\section{Materials}

The dry (lyophilized) venom of cobra the Naja atra (purchased from Vinh Son Snake farming village, Vinh Tuong District, Vinh Phuc Province) was used as a source of RNase. Total RNA from the yeast Torula (purchased from Sigma) was used as a substrate for the determination of RNase activity. Glycine from Prolabo, sodium citrate, citric acid, sodium chloride, sodium hydroxide, hydrochloric acid and other chemicals are analytically pure.

The initial enzyme solution $\left(\mathrm{E}_{0}\right)$ was prepared by dissolving 2-10 mg or more of snake venom in the appropriate buffer solution, and then centrifuged at $10000 \mathrm{rpm}$ for $10 \mathrm{~min}$ to remove the insoluble material.

\section{Methods \\ Heat treatment}

To study the thermostability of the RNase activity in Vietnam cobra venom, several series of enzyme samples with concentrations of $2-10 \mathrm{mg} / \mathrm{ml}$ of lyophilized venom were heating in a water bath at different temperatures from 30 to $100{ }^{\circ} \mathrm{C}$ over in the same period of time (5 min). After thermal treatment, the enzyme samples were cooled on ice and centrifuged at $10.000 \mathrm{rpm}$ for $10 \mathrm{~min}$ to remove the residue of inactivated proteins and then RNase activity in the supernatant liquids was determined, as described below.

\section{Determination of the optimum $\mathrm{pH}$}

For studying the influence of $\mathrm{pH}$ on RNase activity and determining the optimum $\mathrm{pH}\left(\mathrm{pH}_{\mathrm{opt}}\right)$ of the enzyme, RNA hydrolysis reactions were carried out in $10 \mathrm{mM}$ Phosphate buffer (P-buffer) at $\mathrm{pH}$ 5.8-8.0, in $10 \mathrm{mM}$
Glycine buffer (G-buffer) at $\mathrm{pH} 1.5-4.0$ and in $10 \mathrm{mM}$ mixed buffer (M-buffer) at $\mathrm{pH} 1.0$ to 9.5 , prepared in the equal molar ratio (1: 1: 1: 1) from glycine, citrate, phosphate and tris- $\mathrm{HCl}$.

\section{Study the effect of ionic strength}

The influence of ionic strength on RNase activity was studied by performing RNA hydrolysis at different concentrations of G- and M-buffers (from 5 to $100 \mathrm{mM}$ ), $\mathrm{NaCl}$ and $\left(\mathrm{NH}_{4}\right)_{2} \mathrm{SO}_{4}$ (from 0 to $100 \mathrm{mM}$ ), $\mathrm{MgSO}_{4}$ (from 0 to $4 \mathrm{mM}$ ) and EDTA (from 0 to $10 \mathrm{mM}$ ).

\section{Treatment with trypsin}

Venom RNase in the enzyme preparation $\mathrm{E}_{0}$ was incubated with trypsin (at a ratio trypsin/protein in preparation $\mathrm{E}_{0}$ equal to $1 / 13$ ) at $25{ }^{\circ} \mathrm{C}$, and then the RNase activity remaining in the reaction mixture was determined at various time intervals.

\section{Gel-filtration chromatography}

$140 \mathrm{mg}$ of the dried venom of Vietnam cobra Naja atra were separated by a gel-filtration column $(\varnothing 2.5 \times 90 \mathrm{~cm})$ with Sephadex G50sf as a carrier in $0.1 \mathrm{M}$ ammonium acetate buffer $\mathrm{pH} 6.2$ at a flow rate of $15 \mathrm{ml} / \mathrm{h}$, the volume of collected fractions was $5 \mathrm{ml}$. In the case of gel-filtration on a Superdex 75 column $(\varnothing 0.9 \times 60 \mathrm{~cm})$, different amounts of cobra venom (10-50 mg) were used for fractionation, and the chromatographic process was carried out in $10 \mathrm{mM}$ citrate buffer $\mathrm{pH} 5.25$ or in $10 \mathrm{mM}$ phosphate buffer $\mathrm{pH} 7.4$ at a flow rate of $1 \mathrm{ml} / \mathrm{min}$, the volume of collected fractions was $1 \mathrm{ml}$. After chromatography, the ribonucleolytic activity was determined in all fractions obtained as described below.

\section{RNase activity assay}

RNA hydrolysis reactions were carried out in $10 \mathrm{mM}$ glycine buffer $\mathrm{pH} 2.6$ at room temperature for $30 \mathrm{~s}$ in a total volume of $1 \mathrm{ml}$ of the reaction mixture [8]. The hydrolysis reaction is initiated by adding $x \mu \mathrm{l}$ of the enzyme solution in the $(1000-x) \mu$ l of RNA solution prepared in glycine buffer. RNase activity was evaluated by the increase in $\mathrm{OD}_{260}$ of the reaction mixture during the hydrolysis of the RNA substrate. One unit of RNase activity is defined as the amount of enzyme which hydrolyzes RNA causing an increase in $\mathrm{OD}_{260}$ value of the reaction mixture by 1 unit.

\section{Protein determination}

The protein content in the fractions of gel filtration was automatically recorded at a wavelength of $280 \mathrm{~nm}$. 
Table 1 Results of determination of ribonucleolytic activity $\left(A, \mathrm{OD}_{260}\right)$ remained in the supernatant liquids after centrifugation of the heat-treated enzyme samples

\begin{tabular}{|c|c|c|c|c|c|c|c|c|c|c|c|c|}
\hline \multirow[t]{3}{*}{$\mathrm{T}^{\circ} \mathrm{C}$} & \multicolumn{12}{|c|}{ Ribonucleolytic activity remained after heat treatment } \\
\hline & \multicolumn{2}{|c|}{ Series 1} & \multicolumn{2}{|c|}{ Series 2} & \multicolumn{2}{|c|}{ Series 3} & \multicolumn{2}{|c|}{ Series 4} & \multicolumn{2}{|c|}{ Series 5} & \multicolumn{2}{|c|}{ Series 6} \\
\hline & $\mathrm{OD}_{260}$ & $\%$ & $\mathrm{OD}_{260}$ & $\%$ & $\mathrm{OD}_{260}$ & $\%$ & $\mathrm{OD}_{260}$ & $\%$ & $\mathrm{OD}_{260}$ & $\%$ & $\mathrm{OD}_{260}$ & $\%$ \\
\hline 25 & 0.165 & 100.0 & 0.206 & 100.0 & 0.190 & 100.0 & 0.166 & 100.0 & 0.229 & 100.0 & 0.228 & 100.0 \\
\hline 30 & 0.214 & 129.3 & 0.254 & 123.6 & 0.239 & 125.9 & 0.193 & 115.9 & 0.259 & 113.0 & 0.250 & 109.5 \\
\hline 40 & 0.227 & 137.0 & 0.270 & 131.6 & 0.257 & 135.0 & 0.212 & 127.4 & 0.279 & 121.7 & 0.284 & 124.6 \\
\hline 50 & 0.239 & 144.5 & 0.289 & 140.7 & 0.262 & 137.9 & 0.224 & 135.2 & 0.297 & 129.2 & 0.299 & 131.4 \\
\hline 60 & 0.206 & 124.2 & 0.276 & 134.3 & 0.254 & 133.5 & 0.215 & 129.4 & 0.252 & 109.8 & 0.274 & 120.1 \\
\hline 70 & 0.200 & 121.0 & 0.241 & 117.2 & 0.215 & 113.2 & 0.189 & 113.8 & 0.221 & 96.1 & 0.231 & 101.4 \\
\hline 80 & 0.174 & 105.3 & 0.234 & 113.6 & 0.205 & 107.6 & 0.176 & 105.9 & 0.209 & 91.0 & 0.204 & 89.4 \\
\hline 90 & 0.169 & 102.4 & 0.223 & 108.7 & 0.203 & 106.7 & 0.166 & 99.9 & 0.203 & 88.7 & 0.198 & 87.1 \\
\hline 100 & 0.155 & 93.5 & 0.212 & 103.2 & 0.170 & 89.4 & 0.146 & 88.1 & 0.197 & 85.7 & 0.186 & 81.6 \\
\hline
\end{tabular}

\section{Results}

\section{Thermostability of the enzyme}

In experiments studying the thermostability of RNase activity in venom of Vietnam cobra, the enzyme samples were heat-treated as described in the section Methods. The results of the determinination of ribonucleolytic activity remained in the supernatant liquids after centrifugation of several series of heat-treated enzyme samples, are summarized in Table 1, and the curves, illustrating the temperature dependence of the relative activity of RNase, are shown in Fig. 1.

The data in Table 1 and the curves in Fig. 1 showed that RNase activity in venom of Vietnam cobra $N$. atra is highly thermostable. It has the maximum activity after heating the enzyme solution at $50{ }^{\circ} \mathrm{C}$ for $5 \mathrm{~min}$ and in this case the RNase activity was increased by about 29-45\%. Moreover, after boiling for $5 \mathrm{~min}$ in a water bath this

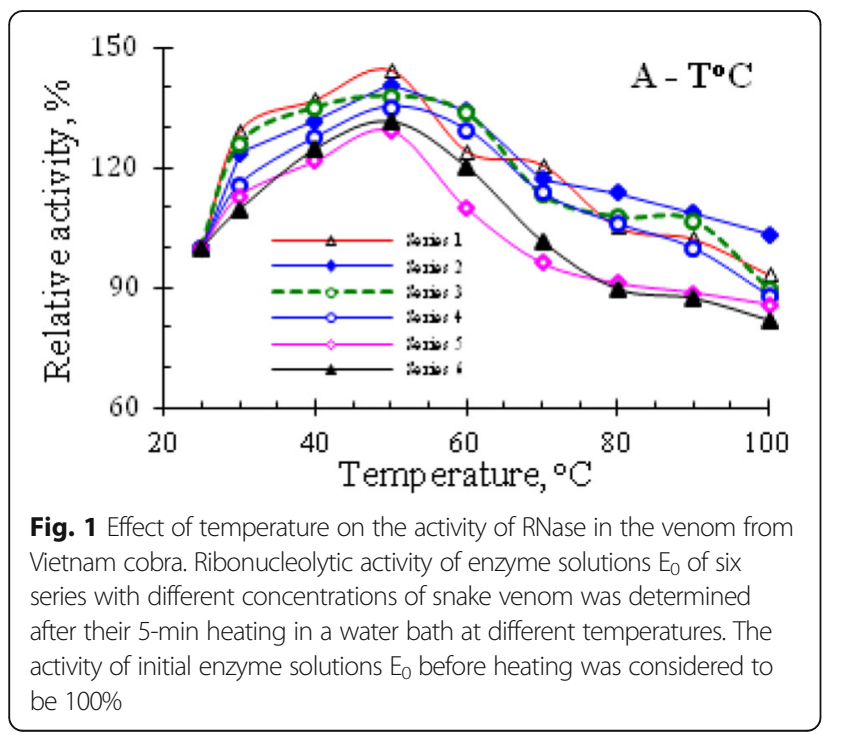

enzyme retained approximately $82-103 \%$ of its original activity.

\section{Effect of $\mathrm{pH}$ on the enzyme activity}

The effect of $\mathrm{pH}$ on the cobra venom RNase was studied by measuring its enzymatic activity at different $\mathrm{pH}$ values of phosphate, glycine, and mixed buffers. The results of these experiments are shown in Fig. 2.

The curves in Fig. 2 showed that the venom RNase of Vietnam cobra had a high catalytic activity in an acid medium: its activity was high in the $\mathrm{pH}$ range from 1.5 to 4.0 in both G- and M-buffers, and was dropped almost linearly in P-buffer when $\mathrm{pH}$ increased from 5.8 to 8.0. As can be seen in Fig. 2, and according to the results obtained, the optimum $\mathrm{pH}\left(\mathrm{pH}_{\mathrm{opt}}\right)$ for RNase activity of Vietnam cobra venom varied in a rather wide range: $\mathrm{pH}_{\mathrm{opt}}=2.58 \pm 0.35$.

\section{Effects of ionic strength}

In the previous section it was shown that venom RNase of Vietnam cobra exhibits the highest activity in an acidic medium, so the effect of ionic strength on the activity of this RNase was studied in the $\mathrm{pH}$ range from 1.5 to 4.0. The results of the experiment for determining the activity of RNase at different concentrations of Gand M-buffers, are summarized in Table 2 and are illustrated in Fig. 3.

As seen in Fig. 3, RNase activity in Vietnam cobra venom is strongly influenced by ionic strength. The enzyme had the highest activity at $10 \mathrm{mM}$ concentration of both G- and M-buffers. In the range of buffer concentrations from 10 to $100 \mathrm{mM}$, venom RNase activity is almost linearly decreased with increasing buffer concentration. Moreover, at $100 \mathrm{mM}$ concentration of these buffers, the enzyme retained $10.5 \%$ and $51 \%$ of its activity, respectively (i.e., the enzyme activity was 10.5 and $51 \%$ of its maximum activity in the corresponding buffers). 

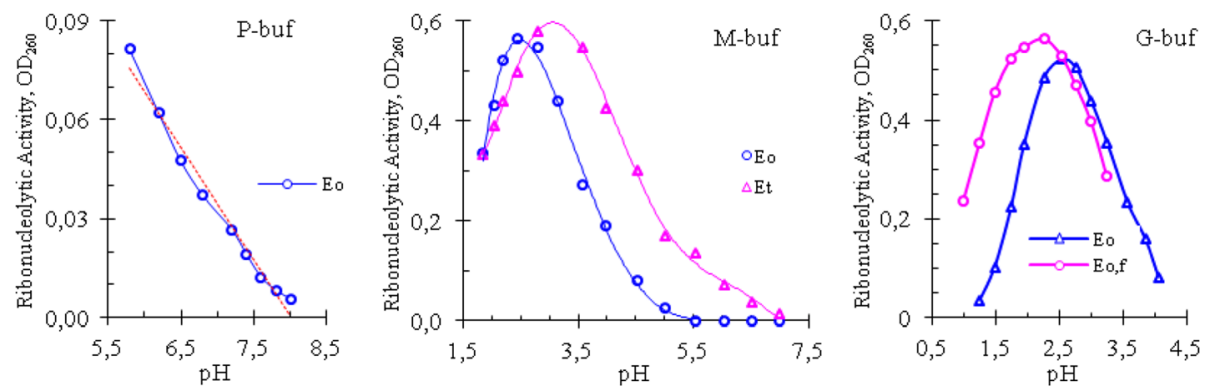

Fig. 2 pH-dependence of ribonucleolytic activity of cobra venom. P-buf - Phosphate buffer; M-buf - mixed buffer; G-buf - Glycine buffer; $E_{0}$ The initial enzyme solution, prepared from lyophilized venom; $E_{0, f}-$ The initial enzyme solution, prepared from fresh venom; $E_{t}-$ The heat-treated (boiled in the water bath for 5 min) enzyme solution $E_{0}$

On the other hand, It is known that $\mathrm{NaCl}$ and $\left(\mathrm{NH}_{4}\right)_{2} \mathrm{SO}_{4}$ are the salts most commonly used in isolation and purification of enzymes and many enzymes require divalent metal ions for their catalysis. Therefore, the effects of these salts, EDTA and $\mathrm{MgSO}_{4}$ on the RNase activity of Vietnam cobra venom are assessed by measuring the enzyme activity in the presence of these substances. The results of these experiments are shown in Fig. 4.

As seen in Fig. 4, cobra venom RNase activity is strongly influenced by $\mathrm{NaCl}$ and $\left(\mathrm{NH}_{4}\right)_{2} \mathrm{SO}_{4}$ : the activity of this enzyme is rapidly reduced with increasing salt concentration. At $100 \mathrm{mM}$ concentration of $\mathrm{NaCl}$, the RNase activity is only $28 \%$ compared to its activity in the absence of this salt, whereas at ammonium sulfate concentration higher $70 \mathrm{mM}$ the venom RNase lost completely its activity. In addition, the activity of this RNase is also considerably reduced in the presence of $\mathrm{MgSO}_{4}$ and EDTA. Venom RNase activity is remained only about $52.6 \%$ at $4 \mathrm{mM}$ concentration of $\mathrm{MgSO}_{4}$ and $46.7 \%$ at $10 \mathrm{mM}$ concentration of EDTA. These data show that $\mathrm{Mg}^{2+}$ ions are not essential for the catalytic activity of RNase from Vietnam cobra venom.

\section{Susceptibility of RNase from Vietnam cobra venom to the proteolytic action of trypsin}

Conformational stability is a very important parameter determining the biological activity of proteins in general and enzymes in particular. In addition to thermal stability, another expression of the conformational stability of protein molecules is their susceptibility to proteolytic action of proteinases - hydrolytic enzymes present in all cells. A curve illustrating the effect of the proteolytic action of trypsin on the RNase from Vietnam cobra venom is shown in Fig. 5.

The curve in Fig. 5 showed that the venom RNase activity is not reduced, but even increased when the crude enzyme solution $E_{0}$ is incubated with trypsin for one day. The enzyme activity began to decrease after a 24-h incubation and RNase still retained about 30\% of its activity after $48 \mathrm{~h}$ of incubation with trypsin. These data indicate that RNase from the venom of Vietnam cobra is very resistant to the proteolytic action of trypsin. This means that RNase from Vietnam cobra venom has a very high conformational stability.

\section{Multiple molecular forms and abnormal distribution of their activity}

According to our preliminary data, RNase activity in the venom of Vietnam cobra $N$. atra is abnormally high [8]. One of the objectives of this work is to find the factors behind this phenomenon. To this end, the proteins of the dried venom of Vietnam cobra are fractionated by gel filtration on a Sephadex G50sf column $(\varnothing 2.5 \times 90 \mathrm{~cm})$. The results of this experiment are shown in Fig. 6.

As shown in Fig. 6, when fractionated by gel filtration on a Sephadex G50sf column, proteins of venom from Vietnam cobra are divided into four conventional protein peaks (1-4) and one peak of low-molecular substances (LMW), as expected.

Table 2 RNase activity of Vietnam cobra venom at different concentrations of buffers

\begin{tabular}{|c|c|c|c|c|c|c|c|c|c|c|c|}
\hline \multirow[t]{2}{*}{ Buffer } & \multirow[t]{2}{*}{ Activity } & \multicolumn{10}{|c|}{ Buffer's concentrations, mM } \\
\hline & & 4 & 5 & 10 & 20 & 30 & 40 & 50 & 60 & 80 & 100 \\
\hline \multirow[t]{2}{*}{ M-buf } & $\mathrm{OD}_{260}$ & - & 0.265 & 0.456 & 0.407 & 0.375 & 0.313 & 0.288 & 0.239 & 0.190 & 0.048 \\
\hline & $\%$ & - & 58.16 & 100.0 & 89.34 & 82.28 & 68.68 & 63.25 & 52.41 & 41.58 & 10.48 \\
\hline \multirow[t]{2}{*}{ G-buf } & $\mathrm{OD}_{260}$ & 0.506 & - & 0.588 & 0.564 & 0.540 & 0.530 & - & 0.470 & 0.366 & 0.300 \\
\hline & $\%$ & 86.10 & - & 100.0 & 95.92 & 91.84 & 90.14 & - & 79.93 & 62.24 & 51.02 \\
\hline
\end{tabular}




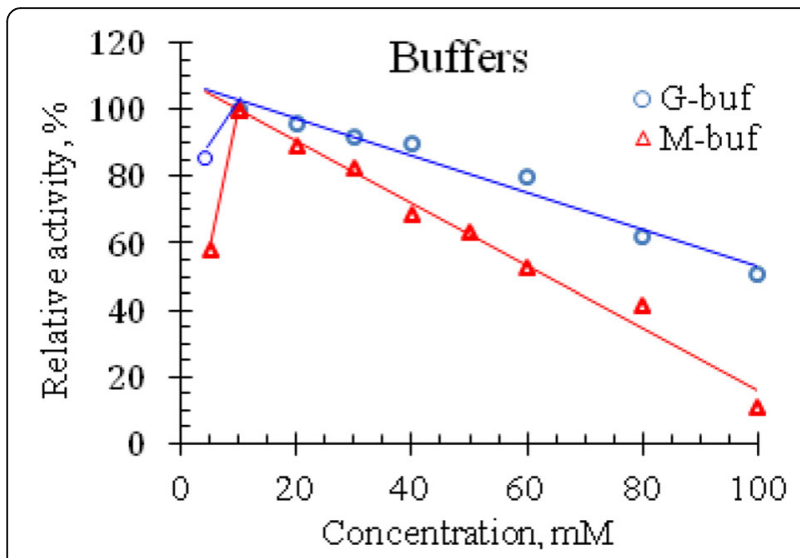

Fig. 3 Effect of buffer concentration on RNase activity in the venom of Vietnam cobra. M-buf - mixed buffer; G-buf - Glycine buffer

Peak 1 consists of components of the venom with molecular weights above $30 \mathrm{kDa}$ (e.g., trimeric phospholipase A2, PLA2) and contains traces of RNase activity. Peak 2 corresponds to fractions of PLA2 and has, as expected, a moderate RNase activity. However, the bulk of the RNase activity is concentrated in peak 4 corresponding to fractions of Kunitz-type proteinase inhibitors (KTPI), and a much smaller portion of the activity is localized in the tail of peak 3 , which is the biggest protein peak and corresponds to fractions of three-finger toxins (TFT, including alpha-neurotoxins and cytotoxins). This distribution of RNase activity in gel filtration fractions is fundamentally contrary to the available data in the literature $[9,38]$, because according to these data, RNase of snake venom has a molecular weight of $12-15 \mathrm{kDa}$ and should be contained in the same fractions as PLA2.

Later we performed a repeated gel filtration of peak 4 under the same conditions and found that its own RNase activity is not scattered on peaks under these chromatographic conditions, and is again present in fractions corresponding to Kunitz inhibitors (i.e., at peak 4), and partly - in the tail of peak 3 (Fig. 6, bottom). Thus, these data can allow suggesting that the abnormally high RNase activity of venom from Vietnam cobra is possibly due to a new type RNase, observed in fractions of Kunitz inhibitors with molecular weight of $6 \mathrm{kDa}$. Gel Filtration on a Superdex 75 column $(\varnothing 0.9 \times 60 \mathrm{~cm})$ also gave similar results: RNase from Vietnam cobra venom is separated into 4 isoforms which differed in molecular size (Fig. 7).

These isoforms are denoted as RNase I, II, III and IV, their molecular weights respectively are $>30 ; 12.94 \pm 1.74$ $(n=10) ; 8.95 \pm 1.34(n=18)$ and $5.93 \pm 0.38 \mathrm{kDa}$ $(n=18)$, which were determined from a calibration curve created with using bovine serum albumin (BSA), ovalbumin, trypsin, RNase $\mathrm{A}$ and insulin as the standard proteins. Note: Sometimes the high molecular weight isoform RNase I is absent and isoform RNase II is often appeared as the left shoulder of isoform RNase III, whereas isoforms RNase III and RNase IV are the main forms and in some experiments we have obtained only these two isoforms. In the experiment presented in Fig. 7, the ribonucleolytic activity of the isoforms RNase I, II, III and IV has the following distribution: 4.5, 19.2, 35.8 and $40.5 \%$, respectively. In general the results of the separation of snake venom RNase on the Superdex 75 column are similar to those that are obtained by separation on the Sephadex G50sf column. These results also reflect the abnomal distribution of RNase activity from the venom of Vietnam cobra.

\section{Discussion}

From the results presented above, we see that RNase in Vietnam cobra venom is a thermostable enzyme. This RNase exhibits the highest catalytic activity after heating enzyme solution for $5 \mathrm{~min}$ at $50{ }^{\circ} \mathrm{C}$ (this thermal treatment increases the enzyme activity by $30-45 \%$ ) and its activity is reduced insignificantly or almost does not change when the enzyme solution is boiled in water bath for $5 \mathrm{~min}$. According to the thermostability, RNase from Vietnam cobra venom is similar to all other enzymes of the RNase A superfamily [12], but this enzyme is differed from RNases in the venoms of cobra Naja oxiana from Central Asia of former Soviet Union and cobra Naja naja from region Guntur in India (RNase from these cobras completely inactivated at $70{ }^{\circ} \mathrm{C}$ [39] or showed the highest activity at $40{ }^{\circ} \mathrm{C}[40]$, respectively).
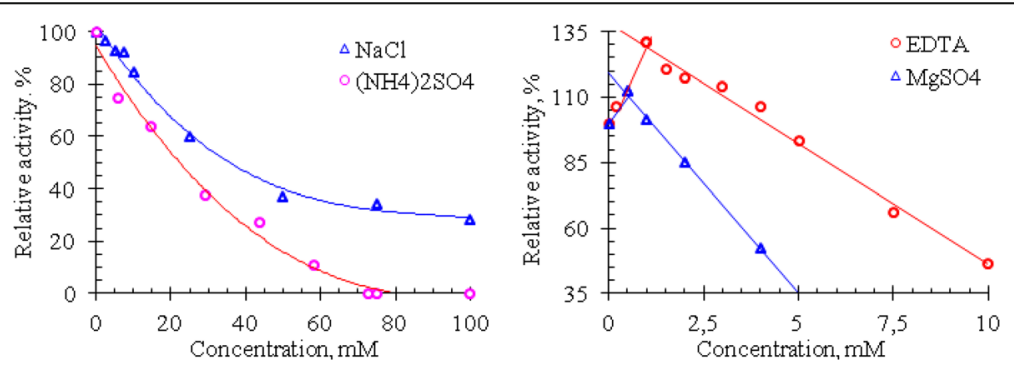

Fig. 4 Effect of salts and EDTA on the activity of RNase in the venom of Vietnam cobra 


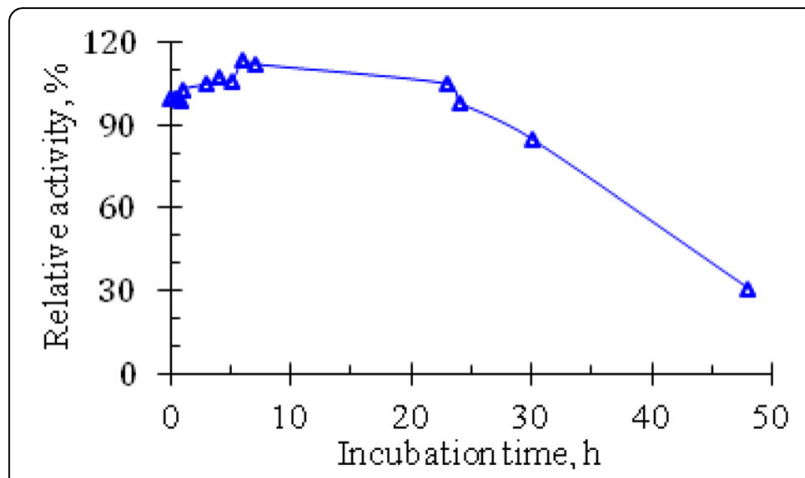

Fig. 5 Effect of the proteolytic action of trypsin on RNase in the venom of Vietnam cobra

If according to thermostability RNase from venom of Vietnam cobra is similar to other enzymes of the RNase A superfamily, but this RNase is differed from all other known members of this superfamily by the dependence on $\mathrm{pH}$ of its ribonucleolytic activity: All known until today enzymes of the RNase A superfamily, including RNases from the venoms of Indian cobra $N$. naja [41] and Central Asian cobra $N$. oxiana of the former Soviet Union [42] have $\mathrm{pH}_{\mathrm{opt}}$ in the $\mathrm{pH}$ range of 6 to 8 , and mostly with $\mathrm{pH}_{\mathrm{opt}}>7$ $[12,43]$, whereas RNase from Vietnam cobra venom is highly active in the acidic $\mathrm{pH}$ range, with $\mathrm{pH}_{\mathrm{opt}}=2.58 \pm 0.35$. Since the optimum $\mathrm{pH}$ of RNase from Vietnam cobra venom is very low, therefore, the RNA hydrolysis reaction catalyzed by this enzyme was carried out in glycine buffer (G-buffer) or in mixed buffer ( $M$-buffer) at $\mathrm{pH}$ 2.6. Although the enzyme is most active at $10 \mathrm{mM}$ concentration of both buffers, at increasing buffers' concentration from 10 to $100 \mathrm{mM}$, the enzyme activity is decreased slowly in G-buffer, but is dropped rapidly in M-buffer, and at buffer concentration of $100 \mathrm{mM}$, venom RNase retains 51 and $10.5 \%$ of its activity in G- and M-buffers, respectively. On the other hand, $\mathrm{NaCl}$ and $\left(\mathrm{NH}_{4}\right)_{2} \mathrm{SO}_{4}$ are the salts often used in the isolation and purification of enzymes, and these salts also significantly decreased the RNase activity in Vietnam
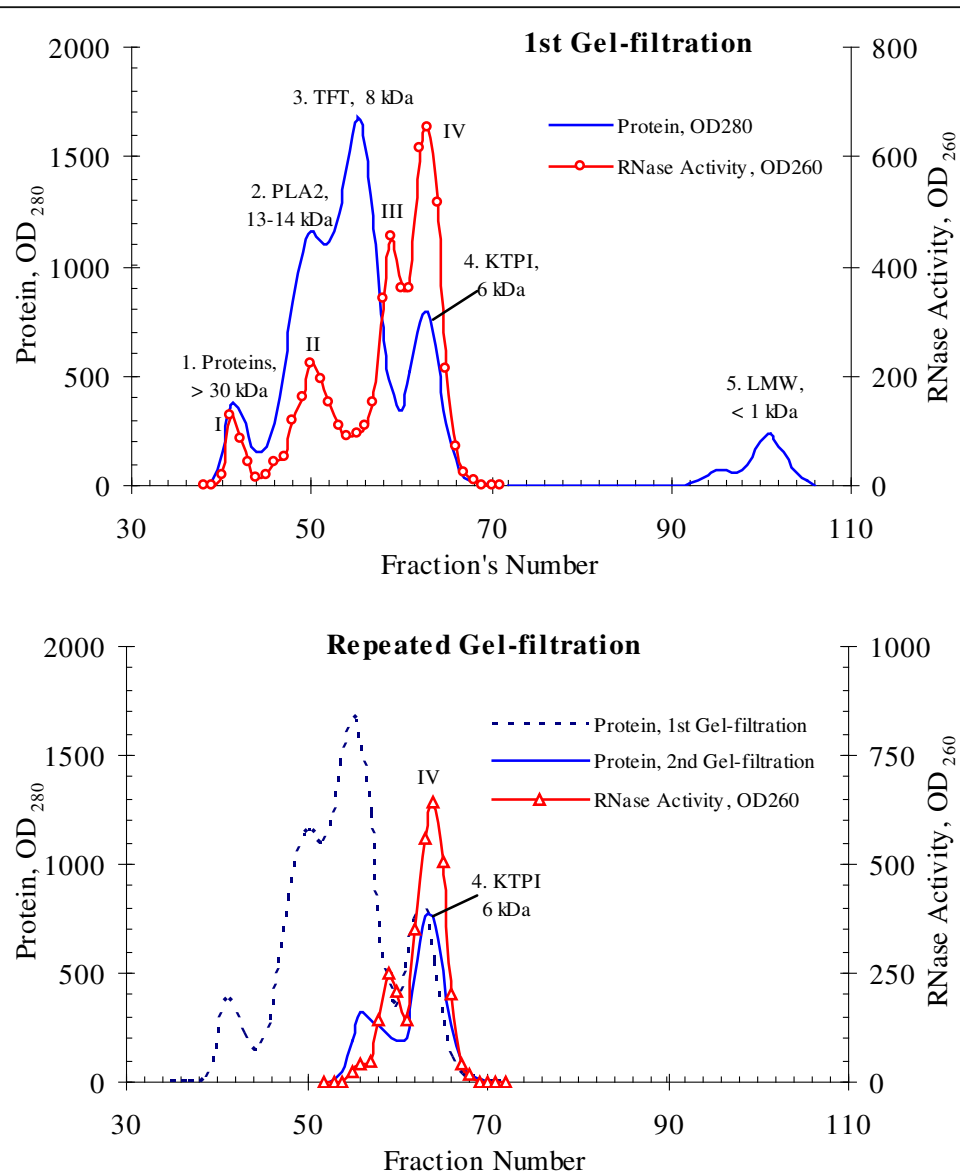

Fig. 6 The elution profiles of proteins of Vietnam cobra venom at gel filtration on a Sephadex G50sf column. The first gel filtration was carried out with the whole cobra venom (top) and repeated gel filtration of peak 4 from the first gel filtration (bottom). KTPI - Kunitz-type proteinase inhibitors, LMW - Low molecular weight substances, PLA2 -Phospholipase A2, TFT - Three-finger toxins 

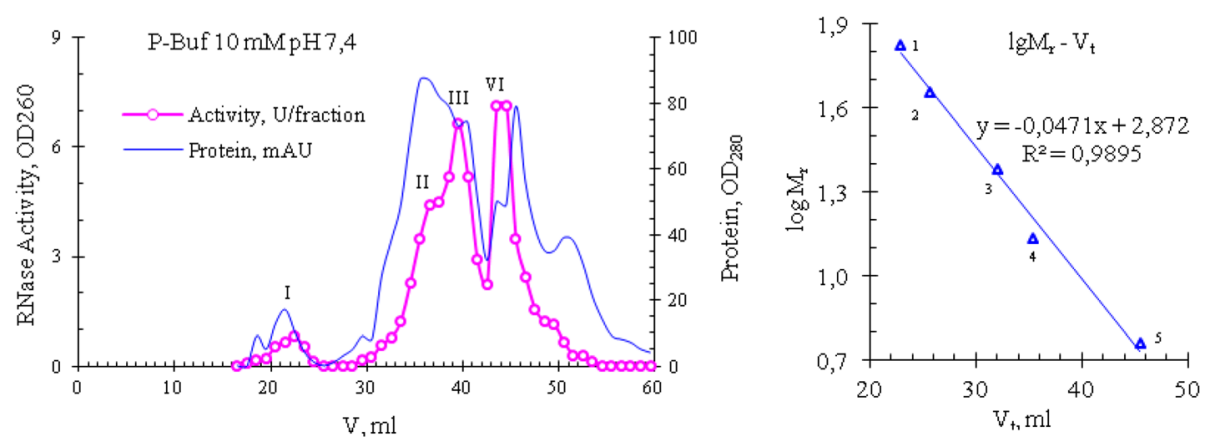

Fig. 7 The elution profile of proteins of Vietnam cobra venom at gel filtration on a Superdex 75 column (left) and calibration curve for determining molecular weights of the enzyme (right). Standard proteins: 1. Bovine serum albumin (BSA, 67 kDa); 2. Ovalbumin (45 kDa); 3. Trypsin (24 kDa); 4. RNase A (13.7 kDa); 5. Insulin (5.8 kDa). Conditions of gel filtration: $10 \mathrm{mM}$ phosphate buffer $\mathrm{pH}$ 7.4; flow rate $1 \mathrm{ml} / \mathrm{min}$

cobra venom: In the presence of $\mathrm{NaCl}$ at $100 \mathrm{mM}$ concentration venom RNase retains only $28 \%$ of activity in comparison to its activity in the absence of this salt, and at ammonium sulfate concentration higher $70 \mathrm{mM}$ the enzyme lost completely its activity. The activity of Vietnam cobra venom RNase is also considerably reduced in the presence of $\mathrm{MgSO}_{4}$ and EDTA. The enzyme has the highest activity at 0.5 and $1 \mathrm{mM}$ of $\mathrm{MgSO}_{4}$ and EDTA, respectively; and its activity is also almost linearly decreased with increasing concentration of $\mathrm{MgSO}_{4}$ (from $0.5 \mathrm{mM}$ to $4 \mathrm{mM}$ ) and EDTA (from $1 \mathrm{mM}$ to $10 \mathrm{mM}$ ). The activity of venom RNase is retained only about $52.6 \%$ at $4 \mathrm{mM}$ concentration of $\mathrm{MgSO}_{4}$ in comparison to its activity in the absence of this salt. This effect of $\mathrm{Mg}$ ions is completely different from the character of their influence on venom RNase from other sources. In the same concentration range, $\mathrm{Mg}^{2+}$ is required for the activity of venom RNase from Indian cobra $N$. naja [40] and increases the activity of venom RNase from cobra $N$. oxiana in Central Asia of the former Soviet Union up to 10 times [39]. Thus, $\mathrm{Mg}^{2+}$ ions, obviously, do not play a role in the catalysis of RNase from Vietnam cobra venom. This is confirmed by the fact that the activity of this enzyme is increased by $25 \%$ in the presence of EDTA at $1 \mathrm{mM}$ concentration. However, the enzyme activity is decreased at $\mathrm{Mg}^{2+}$ ions concentrations higher $1 \mathrm{mM}$. In our opinion, this decrease in enzyme activity at concentrations of EDTA higher $1 \mathrm{mM}$, is not associated with the loss of $\mathrm{Mg}^{2+}$ ions contained in the molecules of enzyme (if enzyme preparation has a certain amount of $\mathrm{Mg}^{2+}$ ), but is probably due to the effect of EDTA anions on the structure of the enzyme, thereby leading to a decrease in RNase activity.

Today we know that some enzymes of the RNase A superfamily such as RNases from several species of frogs $[24,27,37]$ or bovine seminal RNase (BS-RNase) [25, 26], possess cytotoxic activity because these RNases do not interact with ribonuclease inhibitor (RI) in then cytoplasm [44]. These RNases do not interact with RI because of the small size of their molecules (in the case of RNases from frogs) or too large size (in the case of BS-RNase) compared to RNase A and other enzymes of the RNase A superfamily. RNase from frog $R$. pipiens has high anticancer activity, acts specifically on tumor cells, but does not affect normal healthy cells, and therefore it is called onconase. This RNase has a small size; its polypeptide chain is about ten amino acid residues shorter than that of RNase A due to mutations leading to the loss of amino acids which contact RI, so onconase does not interact with RI [27, 29, 45]. Moreover, some studies have shown that the higher conformational stability of RNase, the higher its cytotoxic activity [46]. A very important feature of RNase from Vietnam cobra venom is its low susceptibility to the proteolytic action of trypsin: the activity of this RNase is not lost, is not reduced, and is even increased slightly during the first hours of incubation of enzyme preparation $E_{0}$ with trypsin at $25{ }^{\circ} \mathrm{C}$ (at the ratio of trypsin/protein in the preparation $\mathrm{E}_{0}$, equal to $1 / 13$ ), the catalytic activity of venom RNase started to decline only after $24 \mathrm{~h}$ of incubation. The low susceptibility to the proteolytic action of trypsin and high thermostability are reliable indicators of the conformational stability of protein molecules. These parameters show that RNase from Vietnam cobra venom has very high conformational stability. On the other hand, according to the results of gel filtration chromatography, the main isoforms of RNase (RNase III and RNase IV) from Vietnam cobra venom have very low molecular weights, so they can not interact with RI. These data allow supposing that two low molecular weight isoforms of RNase from Vietnam cobra venom may have cytotoxic activity. This will be the objective of our research in the future. 


\section{Conclusions}

From the obtained results presented above, it can be concluded as follows:

1. RNase from Vietnam cobra venom has the highest catalytic activity in the acidic $\mathrm{pH}$ range, with $\mathrm{pH}_{\text {opt }}=2.58 \pm 0.35$.

2. This RNase has very high conformational stability, which manifests itself in its thermostability and low susceptibility to the proteolytic action of trypsin.

3. The enzyme does not need ions $\mathrm{Mg}^{2+}$ for catalysis. Its activity is considerably reduced due to increasing the ionic strength (concentration of buffer or salts) in the reaction mixture.

4. This RNase has 4 isoforms (RNase I, II, III and IV), with molecular weights, respectively, of more than $30,12.94,8.95$ and $5.93 \mathrm{kDa}$, of which two low molecular weight RNases III and IV are the main isoforms.

\section{Abbreviations}

BSA: Bovine serum albumin; BS-RNase: Bovine seminal ribonuclease; $E_{0}$ : Enzyme solution prepared from lyophilized venom; $E_{0,}$, Enzyme solution prepared from fresh venom; $E_{t}$ : The heat-treated (boiled in the water bath for 5 min) enzyme solution $E_{0}$; G-buffer: Glycine buffer; KTPI: Kunitz-type proteinase inhibitors; LMW: Low molecular weight substances; $M-$ buffer: Mixed buffer; P-buffer: Phosphate buffer; $\mathrm{pH}_{\text {opt: }}$ Optimum pH; PLA2: Phospholipase A2; RI: Ribonuclease inhibitor: RNase A: Bovine pancreatic ribonuclease; RNase: Ribonuclease; TFT: Three-finger toxins

\section{Acknowledgements}

This work was carried out with the financial support of international cooperation project between the Vietnam Academy of Science and Technology and the Russian Foundation for Basic Research, Project codes: VAST.HTQT.NGA.07/15-16 and 15-54-54012_Bьeт.

\section{Funding}

This work received funding from the Vietnam Academy of Science and Technology (VAST) and the Russian Foundation for Basic Research (RFBR).

\section{Availability of data and materials}

Please contact author for data requests.

\section{Authors' contributions}

TVN carried out the experiments on studying properties of RNase (including conformational stability of the enzyme, pH-dependance of RNase activity and influence of ionic strength on RNase activity). AVO performed the experiments on gel filtration chromatography. Both authors were responsible for writing the manuscripts, interpreting the data, added scientific comments, and approved the final version of the manuscript.

\section{Ethics approval and consent to participate}

Not applicable.

\section{Consent for publication}

Not applicable.

\section{Competing interests}

The authors declare that they have no competing interests.

\section{Publisher's Note}

Springer Nature remains neutral with regard to jurisdictional claims in published maps and institutional affiliations.

\section{Author details}

Institute of Biotechnology, Vietnam Academy of Science and Technology (VAST), Hanoi, Vietnam. ${ }^{2}$ Shemyakin-Ovchinnikov Institute of Bioorganic Chemistry, Russian Academy of Sciences (RAS), Moscow, Russia.

Received: 8 March 2017 Accepted: 22 June 2017

Published online: 25 September 2017

References

1. Rosamond W, Flegal K, Friday G, Furie K, Go A, Greenlund K, et al. Heart disease and stroke statistics-2007 update. A report from the American Heart Association statistics committee and stroke statistics subcommittee. Circulation. 2007;115:e69-e171. http://circ.ahajournals.org/content/115/5/ e69. Accessed 5 July 2017

2. Patlak M. From viper's venom to drug design: treating hypertension. FASEB J 2004;18(3):421. PMID: 15003987. https://www.faseb.org/Portals/2/PDFs/ opa/venom.pdf. Accessed 5 July 2017.

3. Gomes A, Ghosh S, Ghosh S. et al. Anti-osteoarthritic activity of Bungarus fasciatus venom fraction BF-F47 involving molecular markers in the rats. Toxicon 2016;1 18:43-46. http://www.sciencedirect.com/science/article/pii/ S004101011630112X. Accessed 5 July 2017.

4. Jain D, Kumar S. Snake venom: a potent anticancer agent. Asian Pac J Cancer Prev. 2012;13(10):4855-60. https://www.researchgate.net/publication/ 233937869_Snake_Venom_A_Potent_Anticancer_Agent. Accessed 5 July 2017

5. Vyas VK, Brahmbhatt K, Bhatt H, Parmar U, Patidar R. Therapeutic potential of snake venom in cancer therapy: current perspectives. Asian Pac J Trop Biomed. 2013;3(2):156-62.

6. Zouari-Kessentini R, Srairi-Abid N, Bazaa A, El Ayeb M, Luis J, Marrakchi N. Antitumoral potential of Tunisian snake venoms secreted phospholipases A2. Biomed Res Int. 2013;2013:9. http://dx.doi.org/10.1155/2013/391389. Accessed 12 June 2017

7. Making Medicines from Snake Venom. https://biologybiozine.com/2012/11/ 01/making-medicine-from-snake-venom/. Accessed 5 July 2017.

8. Van Thiet N. Study on ribonucleolytic activity of cobra. J Med Mater. 2002; 7(6):181-5.

9. Dhananjaya BL, D'souza CJM. An overview on nucleases (DNase, RNase, and phosphodiesterase) in snake venoms. Biochem Mosc. 2010;75(1):1-6. https:// www.researchgate.net/publication/42439895_An_Overview_on_Nucleases_ DNase_RNase_and_Phosphodiesterase_in_Snake_Venoms. Accessed 5 July 2017

10. Snake Venom. Types of Snake Venom. http://www.chm.bris.ac.uk/ webprojects2003/stoneley/types.htm. Accessed 5 July 2017.

11. Beintema JJ, Kleineidam RG. The ribonuclease a superfamily: general discussion. Cell Mol Life Sci. 1998;54:825-32.

12. Sorrentino S, Libonati M. Structure-function relationships in human ribonucleases: main distinctive features of the major RNase types. FEBS Lett. 1997;404(1):1-5. http://onlinelibrary.wiley.com/doi/10.1016/S00145793(97)00086-0/full. Accessed 5 July 2017

13. Cho S, Zhang J. Zebrafish Ribonucleases are bactericidal: implications for the origin of the vertebrate RNase a Superfamily. Mol Biol Evol. 2007:24(5):1259-68.

14. Hooper LV, Stappenbeck TS, Hong CV, Gordon JI. Angiogenins: a new class of microbicidal proteins involved in innate immunity. Nat Immunol. 2003;4(3):69-73.

15. Lehrer RI, Szklarek D, Barton A, Ganz T, Hamann KJ, Gleich GJ. Antibacterial properties of eosinophil major basic protein and eosinophil cationic protein. J Immunol. 1989;142(12):4428-34. http://www.jimmunol.org/content/142/ 12/4428. Accessed 5 July 2017

16. Pulido D, Arranz-Trullén J, Prats-Ejarque G, Velázquez D, Torrent M, Moussaoui M, et al. Insights into the antimicrobial mechanism of action of human RNase6: structural determinants for bacterial cell agglutination and membrane permeation. Int J Mol Sci. 2016;17:552

17. Pulido D, Torrent M, Andreu D, Nogués MV, Boix E. Two human host defense ribonucleases against mycobacteria, the eosinophil cationic protein (RNase 3) and RNase 7. Antimicrob Agents Chemother. 2013;57:3797-805.

18. Rudolph B, Podschun R, Sahly H, Schubert S, Schröder JM, Harder J. Identification of RNase 8 as a novel human antimicrobial protein. Antimicrob Agents Chemother. 2006;50(9):3194-6. http://aac.asm.org/ content/50/9/3194.full. Accessed 5 July 2017 
19. Tao F, Fan M, Zhao W, Lin Q, Ma R. A novel cationic ribonuclease with antimicrobial activity from Rana dybowskii. Biochem Genet. 2011;49:369-84.

20. Bedoya VI, Boasso A, Hardy AW, Rybak S, Shearer GM, Rugeles MT. Ribonucleases in HIV type 1 inhibition: effect of recombinant RNases on infection of primary T cells and immune activation-induced RNase Gene and Protein expression. AIDS Res Hum Retrovir. 2006;22(9):897-907. doi:10. 1089/aid.2006.22.897

21. Domachowske JB, Bonville CA, Dyer KD, Rosenberg HF. Evolution of antiviral activity in the ribonuclease a gene superfamily: evidence for a specific interaction between eosinophil-derived neurotoxin (EDN/RNase 2) and respiratory syncytial virus. Nucleic Acids Res. 1998;26(23):5327-32.

22. Domachowske JB, Dyer KD, Adams AG, Leto TL, Rosenberg HF. Eosinophil cationic protein/RNase 3 is another RNase A-family ribonuclease with direct antiviral activity. Nucleic Acids Res. 1998;26:3358-63.

23. Domachowske JB, Dyer KD, Bonville CA, Rosenberg HF. Recombinant human eosinophil-derived neurotoxin/RNase 2 functions as an effective antiviral agent against respiratory syncytial virus. J Infect Dis. 1998;177:1458-64.

24. Huang H-C, Wang S-C, Leu Y-J, Lu S-C, Liao Y-D. The Rana catesbeiana rcr gene encoding a cytotoxic ribonuclease. Tissue distribution, cloning purification, cytotoxicity, and active residues for RNase activity. J Biol Chem. 1998;273:6395-401.

25. Kim JS, Soucek J, Matousek J, Raines RT. Mechanism of ribonulcease cytotoxicity. J Biol Chem. 1995;270(52):31097-102.

26. Kim JS, Sousek J, Matousek J, Raines RT. Structural basis for the biological activities of bovine seminal ribonuclease. J Boil Chem. 1995;270(18):10525-30.

27. Leland PA, Raines RT. Cancer chemotherapy-Rionucleases to the rescue. Biol Chem. 2001;8:405-13.

28. Raines RT. Ribonuclease a: from model system to cancer chemotherapeutic. In: Frey PA, Northrop DB, editors. Enzymatic mechanism. Washington DC: IOC press; 1999. p. 235-49. https://biochem.wisc.edu/sites/default/files/labs/ raines/pdfs/Raines1999.pdf. Accessed 5 July 2017.

29. Wu Y, Mikulski SM, Ardelt W, Rybark SM, Youle RJ. A cytotoxic ribonuclease: study of the mechanism of onconase cytotoxicity. J Biol Chem. 1993; 268(14):10686-10693. PMID: 8486718. https://www.ncbi.nlm.nih.gov/ pubmed/8486718. Accessed 5 July 2017

30. Shcheglovitova O, Maksyanina E, lonova I, Rustam'yan YL, Komolova G. Cow milk angiogenin induces cytokine production in human blood leukocytes. Bull Exp Biol Med. 2003;135:158-60.

31. Tamgurrini M, Scala G, Verde C, Ruocco MR, Parente A, Venuta S, et al. Immunosuppressive activity of bovine seminal RNase on T-cell proliferation. Eur J Biochem. 1990;190(1):145-8

32. Yang $D$, Chen $Q$, Rosenberg HF, Rybak SM, Newton DL, Wang ZY, et al. Human ribonuclease a superfamily members, eosinophil-derived neurotoxin and pancreatic ribonuclease, induce dendritic cell maturation and activation. J Immunol. 2004;173:6134-42.

33. Goo SM, Cho S. The expansion and functional diversification of the mammalian Ribonuclease a Superfamily epitomizes the efficiency of Multigene families at generating biological novelty. Genome Biol Evol. 2013:5:2124-40

34. Koczera P, Martin L, Marx G, Schuerholz T. The Ribonuclease a Superfamily in humans: canonical RNases as the buttress of innate immunity. Int J Mol Sci. 2016;17(8):1278.

35. Sorrentino S. The eight human "canonical" ribonucleases: molecular diversity, catalytic properties, and special biological actions of the enzyme proteins. FEBS Lett. 2010;584:2194-200.

36. Gupta SK, Haigh BJ, Griffin FJ, Wheeler TT. The mammalian secreted RNases: mechanisms of action in host defense. Innate Immun. 2013:19:86-97.

37. Irie M, Nitta K, Nonaka T. Biochemistry of frog ribonucleases. Cell Mol Life Sci. 1998;54:775-84.

38. Fry BG, Scheib H, de LM I, Junqueira de Azevedo I, Silva DA, Casewell NR. Novel transcripts in the maxillary venom glands of advanced snakes. Toxicon. 2012;59(7-8):696-708.

39. Vasilenko SK, Babkina GT. Isolation and properties of ribonuclease isolated from cobra venom. Biokhimiia. 1965:30(4):705-712. [Article in Russian] PMID: 5894094. https://www.ncbi.nlm.nih.gov/pubmed/5894094. Accessed 5 July 2017

40. Mahalakshmi YV, Jagannadham MV, Pandit MW. Ribonuclease from cobra snake venom: purification by affinity chromatography and further characterization. IUBMB Life. 2000:49:309-16. http://onlinelibrary.wiley.com/ doi/10.1080/15216540050033186/epdf. Accessed 5 July 2017
41. Mahalakshmi $\mathrm{Y}$, Pandit MW. The new ribonuclease from cobra venom (Naja naja) showing specificity towards cytidylic acid. Biochem Biophys Res Commun. 1987;145(2):740-8. http://documents.tips/documents/a-newribonuclease-from-cobra-venom-naja-naja-showing-specificity-towards. html\#. Accessed 5 July 2017

42. Babkina GT, Vasilenko SK. Nuclease activity of the venom of central Asian snakes. Biokhimiya. 1964;29(2):268-272. [Article in Russian] PMID: 14207641. https://www.ncbi.nlm.nih.gov/pubmed/14207641. Accessed 5 July 2017

43. Raines RT. Ribonuclease a. Chem Rev. 1998;98:1045-65.

44. Haigis MC, Kurten EL, Raines RT. Ribonuclease inhibitor as an intracellular sentry. Nucleic Acids Res. 2003;31:31024-32.

45. Ardelt W, Mikulski SM, Shogen K. Amino acid sequence of an anti-tumor protein from Rana pipiens Oocytes and early embryos. Homology to pancreatic ribonucleases. J Biol Chem 1991;266(1):245-251. PMID:1985896. http://www.jbc.org/content/266/1/245.full.pdf. Accessed 5 July 2017.

46. Klink TA, Raines RT. Conformational stability is a determinant of ribonuclease cytotoxicity. J Biol Chem. 2000;275(23):17463-7.

\section{Submit your next manuscript to BioMed Central and we will help you at every step:}

- We accept pre-submission inquiries

- Our selector tool helps you to find the most relevant journal

- We provide round the clock customer support

- Convenient online submission

- Thorough peer review

- Inclusion in PubMed and all major indexing services

- Maximum visibility for your research

Submit your manuscript at www.biomedcentral.com/submit

) Biomed Central 